\title{
Assessment of the relative catch performance of hake, red mullet and striped red mullet in a modified trawl extension with T90 netting
}

\author{
Iván Sola, Francesc Maynou \\ Institut de Ciències del Mar, CSIC, Psg Marítim de la Barceloneta 37-49, 08003 Barcelona, Spain. \\ (IS) E-mail: ivansolaccmar@gmail.com. ORCID iD: http://orcid.org/0000-0003-2972-614X \\ (FM) (Corresponding author) E-mail: maynouf@icm.csic.es. ORCID iD: http://orcid.org/0000-0001-7200-6485
}

\begin{abstract}
Summary: We studied the relative catch performance of a modified trawl fitted with an extension piece using a $90^{\circ}$ turned mesh (T90) in comparison with a standard trawl net used in NW Mediterranean bottom trawl fisheries employing a diamond mesh net. The comparison was made by means of paired experimental hauls using the same fishing vessel with alternate deployments of the standard net (control) and the experimental net. We used the catch comparison approach for three target species of the fishery: European hake, red mullet and striped red mullet. Our results show that the experimental net significantly reduces the catches of small-size hake and red mullet (though there was no discernible difference for striped red mullet), reducing unwanted catches of regulated species under the Landings Obligation. The overall catch rates of hake, pooled over all sizes, also increased by an estimated $50 \%$, while the catch rates of red mullet and striped red mullet were significantly lower. However, considering all commercial species, the experimental net produced losses of commercial catch and income estimated at $17 \%$ and $18 \%$, respectively, which may pose a barrier to the adoption of this relatively simple, inexpensive solution.
\end{abstract}

Keywords: catch comparison; demersal trawl fisheries; T90 net; mesh size; Mediterranean Sea.

Comparación del rendimiento relativo de captura de merluza, salmonete de fango y salmonete de roca en un arte de arrastre modificado con una extensión con malla T90

Resumen: Estudiamos el rendimiento relativo de captura de un arte de arrastre con una pieza de extensión con malla girada $90^{\circ}$ (T90) en comparación al arte de arrastre estándar usado en una pesquería del Mediterráneo noroccidental que usa extensión de malla romboidal. La comparación se llevó a cabo mediante lances experimentales pareados usando el mismo barco de pesca con lances alternos de la red estándar (control) y la red experimental. Esta comparación de captura se hizo para 3 especies objetivo de la pesca, la merluza, el salmonete de fango y el salmonete de roca. Los resultados muestran que la red experimental redujo de manera significativa las capturas de individuos pequeños de merluza y salmonete de fango (pero no se detectó efecto significativo en el salmonete de roca), contribuyendo a reducir las capturas no deseadas de especies reguladas por la Obligación de Desembarco. Las tasas de captura de merluza, promediadas para todas las tallas, aumentaron en un 50\%, mientras que las tasas de captura de los dos salmonetes fueron significativamente inferiores. La red experimental produjo pérdidas adicionales de captura comercial e ingresos, que se estiman en 17 y $18 \%$, respectivamente, lo que puede significar una barrera para la adopción de esta solución sencilla y barata.

Palabras clave: comparación de capturas; pesquerías de arrastre; red T90; tamaño de malla; mar Mediterráneo.

Citation/Como citar este artículo: Sola I., Maynou F. 2018. Assessment of the relative catch performance of hake, red mullet and striped red mullet in a modified trawl extension with T90 netting. Sci. Mar. 82S1: 19-26. https://doi.org/10.3989/ scimar.04711.04A

Editor: M. Demestre.

Received: September 14, 2017. Accepted: March 20, 2018. Published: May 15, 2018.

Copyright: (c) 2018 CSIC. This is an open-access article distributed under the terms of the Creative Commons Attribution 4.0 International (CC BY 4.0) License.

\section{INTRODUCTION}

The EU discards ban embedded in Art. 15 of EC 1380/2013 EC 2013, or the Landing Obligation, is aimed at reducing discards in EU fisheries and working towards more selective fishing by incentivizing fishers to apply appropriate technical solutions, among other changes in fishing practices. The policy objective behind the Landing Obligation is the perception that fisheries discards are a structural deficiency 
of European fisheries (EC 2012) and that resources that can be used productively in the maritime economy are wasted. The discards ban aims at rationalizing the fishing process by means of more selective gears and sustainable practices (Gullestad et al. 2015). In Mediterranean fisheries, the quantity of discards is perceived to be high, but with important variation across fleet segments or fishing gear (Uhlmann et al. 2014). Bottom trawl fisheries are among the fisheries with the highest amount of discards, both total and of regulated species. For example, Tsagarakis et al. (2014) estimate discard rates of $20 \%$ to $65 \%$ of the total catch in Spanish Mediterranean bottom-trawl fisheries, while discards of undersize individuals of regulated species such as Trachurus spp. or Sparidae vary from $18 \%$ to $77 \%$ of the catch of each species (Bellido et al. 2017). However, the quantity of discards is generally known with low precision due to the high variability in the quantity of discards, even within a single fishery, because of the varied reasons for discarding (Martinet et al. 2007, Uhlmann et al. 2014).

The Landing Obligation entered into force progressively, with the discards ban in small pelagics fisheries effective as of 1 January 2015 and its application to all regulated marine species by 1 January 2019. In western Mediterranean bottom trawl fisheries, the discards ban for species that define the fisheries, the European hake Merluccius merluccius and the red mullet Mullus barbatus, entered into force on 1 January 2017. With the current legal bottom-trawl mesh sizes of $40 \mathrm{~mm}$ (square mesh) or $50 \mathrm{~mm}$ (diamond mesh), it is not possible to avoid catching unwanted individuals of these species, and particularly so for $M$. merluccius, which has an estimated mean retention length of 10 to $16 \mathrm{~cm}$ TL in these meshes, compared with a minimum conservation reference size (MCRS) of $20 \mathrm{~cm}$ (Bahamon et al. 2006, Guijarro and Massutí 2006, Sala and Luchetti 2011).

Investigating the effect of simple modifications to the current bottom trawl is interesting because these modifications may work towards reducing unwanted bycatch without undue changes to the fishing practices of fishers or expensive modifications. It is important to note that the Landing Obligation may result in additional sorting and handling costs estimated at $0.50 € / \mathrm{kg}$ or higher (Sartor et al. 2016), hence the importance of devising inexpensive solutions that mitigate the effects of the Landing Obligation without imposing excessive costs.

The objective of this work is to investigate the relative catch performance of a simple modification to the extension piece of a bottom trawl with regard to the two species that characterize the fishery, the European hake Merluccius merluccius and the red mullet Mullus barbatus, with additional data on the striped red mullet $M$. surmuletus, which is also caught in this fishery. Our research focused on the substitution of a standard diamond-mesh extension piece of $53 \mathrm{~mm}$, as used in NW Mediterranean bottom trawls, with a similar piece with netting turned $90^{\circ}$ (T90). This modification is based on the improved selection properties that this netting has shown when used in codends in Northern European fisheries (Madsen et al. 2012, Wienbeck et

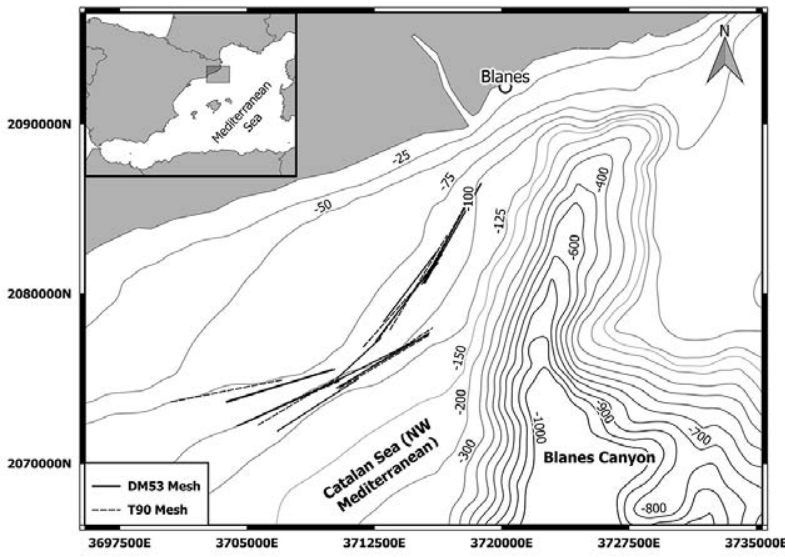

Fig. 1. - Study area.

al. 2011), due to increased resistance of the T90 netting to close under pressure compared with the traditional orientation.

\section{MATERIALS AND METHODS}

\section{Data}

The study area comprises two commercial fishing grounds of the continental shelf of NE Spain (Fig. 1). The shallower fishing ground, "Les Quaranta", covers $21 \mathrm{~km}^{2}$ on sand and gravel bottoms of 60-90 m depth. The deeper fishing ground, "Els Capets", covers 24 km² on muddy-sand bottoms between 90 and $120 \mathrm{~m}$ depth. Both fishing grounds are routinely operated by the local trawl fleet of the port of Blanes, practising a mixed bottom trawl fishery targeting Merluccius merluccius, Mullus spp. and various cephalopods and finfish.

The sampling design consisted of paired hauls using a single local commercial fishing vessel of 15 $\mathrm{m}$ LOA and $261 \mathrm{~kW}$, alternating the standard extension piece used in the area with the experimental T90 extension piece over consecutive days over the same geographical coordinates (Fig. 1). The experiment was carried out during daytime in 2016 on 10-11 August, 26-27 September and 13-14 December, with a total of 24 fishing operations corresponding to 12 pairs. Four to five one-hour hauls were performed daily at a towing speed of 2.7-2.9 knots. The specifications of the fishing gear are shown in Table 1.

The control net, referred to hereafter as DM53, was fitted with a codend of 40-mm square-mesh knotting $\left(45^{\circ}\right)$ and a 53-mm diamond-mesh knotting $\left(0^{\circ}\right)$ exten-

Table 1. - Nominal sizes of the standard (DM53) and the experimental net (T90).

\begin{tabular}{lcc}
\hline Codend/entension parameters & DM53 & T90 \\
\hline Nominal mesh size, codend (mm) & 40 & 40 \\
Nominal mesh size, extension (mm) & 53 & 50 \\
Netting material & $\mathrm{PE}$ & $\mathrm{PE}$ \\
$\mathrm{N}^{\circ}$ meshes around codend circum. & 130 & 130 \\
$\mathrm{~N}^{\mathrm{o}}$ meshes codend length & 55 & 55 \\
codend length (m) & 1.40 & 1.42 \\
$\mathrm{~N}^{\circ}$ meshes extension circum. & 206 & 140 \\
$\mathrm{~N}^{o}$ mesh extension length & 81 & 100 \\
Longitudinal extension length $(\mathrm{m})$ & 5.15 & 4.36 \\
\hline
\end{tabular}



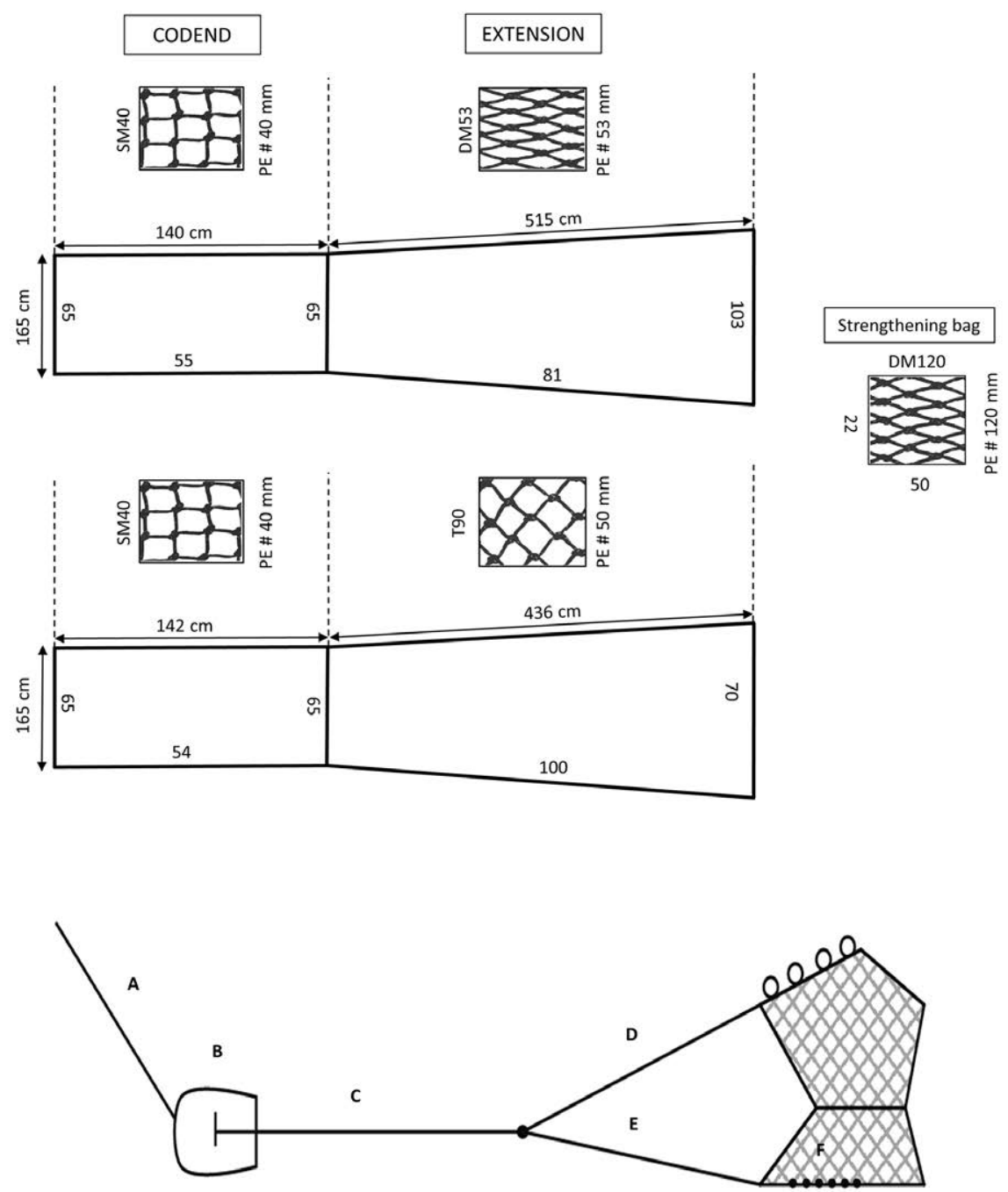

Fig. 2. - Characteristics of the trawl with details of the control and experimental aft parts of the net. In the lower panel: A, wire $\emptyset 16 \mathrm{~mm}$, 265-330 m; B, trawl door (1250×770 mm), -110 kg; D, combinations rope Ø $22 \mathrm{~mm}, 220 \mathrm{~m}$; E, wire Ø14 mm, $23 \mathrm{~mm} ; \mathrm{F}$, chain, $3 \mathrm{~m}$.

sion piece (Fig. 2), following the standard trawl used in the area, which complies with the local fisheries regulation (EC 1967/2006: EC 2006). In the experimental net, the netting in the extension piece was replaced with a 50-mm diamond mesh mounted in T90 orientation (T90, Hansen 2004).

After hauling in the catch, the target species $M$. merluccius and Mullus spp. were sorted, weighed and sized (cm TL) individually, while the rest of the commercial catch was identified to species level and weighed. No subsampling of the catch was necessary given the number of specimens caught.

\section{Statistical analysis}

\section{Catch comparison analysis}

The experimental setup lacked a small mesh cover or other similar device to quantify the number of individuals passing through the extension piece, precluding the computation of absolute selectivity. For this reason, we chose the catch comparison method for the analysis of the experimental results. For each target species, we compared the catch efficiency of the standard trawl (control; 1) with that of the experimental trawl (2), based on the catch comparison method (Holst and Revill 2009) used in Krag et al. (2014) and Sistiaga et al. (2015), for example. This method estimates the average, relative change in length-dependent catch efficiency. For our set of 12 comparisons, the experimental average catch comparison rate $\left(C C_{l}\right)$ is given by the following expression:

$$
C C_{l}=\frac{\sum_{i=1}^{12} n 2_{l_{i}}}{\sum_{i=1}^{12} n 1_{l_{i}}+\sum_{i=1}^{12} n 2_{l_{i}}}
$$

where $n 1_{l i}$ and $n 2_{l i}$ are the number of fish measured in each length class $l$ in the control and experimental trawls, respectively (Sistiaga et al. 2015). The experimental $C C_{l}$ can be modelled by the following functional form (Krag et al. 2014):

$$
C C(l, v)=\frac{e^{f\left(l, q_{0} \cdots q_{k}\right)}}{1+e^{f\left(l, q_{0} \cdots q_{k}\right)}}
$$

where $f$ is a polynomial of order $k$ with coefficients $q_{0}$ to $q_{k}$ so $v=\left(q_{0}, \ldots, q_{k}\right)$. Equation (2) gives the probabil- 

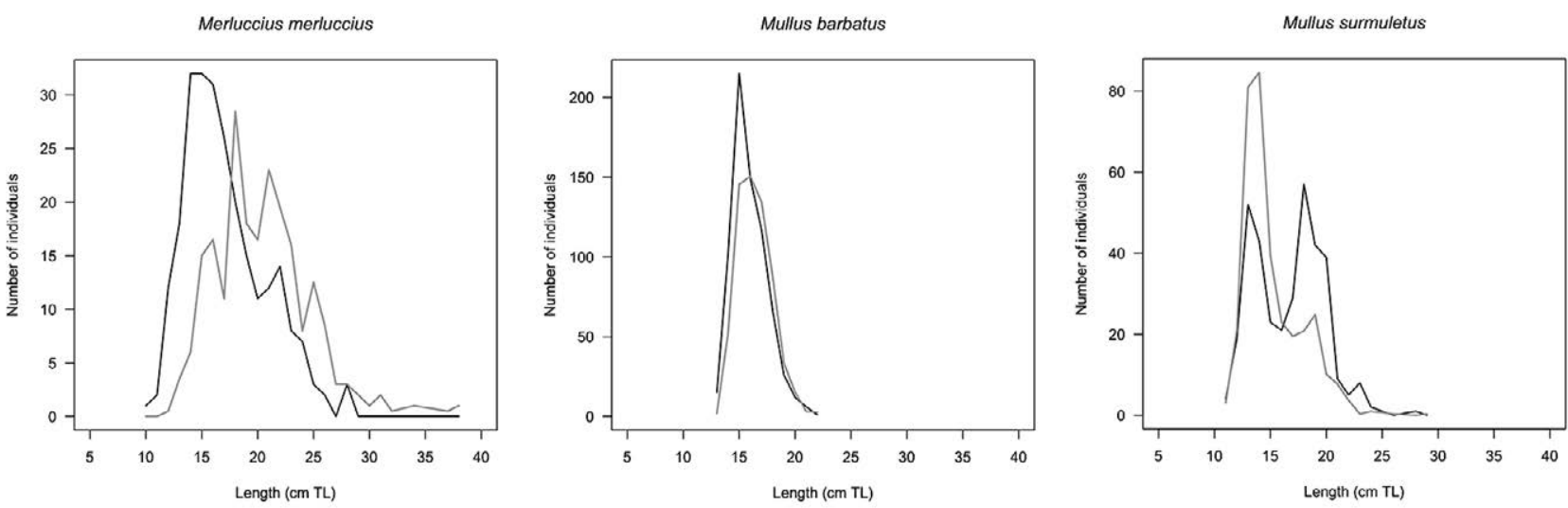

Fig. 3. - Length frequencies of the target species. Black line, standard configuration with a 53-mm diamond mesh; grey line, experimental trawl fitted with 50-mm T90 mesh extension.

ity of catching a fish of length $l$ with trawl 2 provided it was captured by any of the two trawls. A value of $C C(l$, $v)=0.5$ implies that the likelihood of capturing a fish of size $l$ is the same for the two trawls (i.e. both trawls would have the same catch efficiency). The values of the polynomial coefficients in $v$ are estimated by minimizing the log-likelihood:

$$
L L=-\sum_{l}\left(n 1_{l} \cdot \log (1-C C(l, v))+n 2_{l} \cdot \log (1-C C(l, v))\right)
$$

where $n 1_{l}$ and $n 2_{l}$ are the numbers of fish of length 1 summed over hauls.

Following Krag et al. (2014), we tested all possible polynomials up to the fourth degree, i.e. $2^{5}$ combinations of parameters $q_{0}, q_{1}, q_{2}, q_{3}, q_{4}$. Selection of the best model among the 32 candidate models was based on choosing the model with the lowest Akaike information criterion (Akaike 1974). We used the double bootstrap approach with 10000 repetitions to estimate the $95 \%$ confidence limits (Efron 1982) of the polynomial coefficients and the $C C(l, v)$ curve for length classes with 10 individuals or more (10 to $38 \mathrm{~cm}$ TL for hake, 13 to $22 \mathrm{~cm}$ TL for red mullet, and 11 to $29 \mathrm{~cm}$ for the striped red mullet). The double bootstrap method accounts for between-haul variation and within-haul uncertainty on the size structures, and was applied by resampling (with replacement) among the 12 haul pairs and resampling (with replacement) among the length frequencies.

A significant difference in catch efficiency between the two trawls was determined when the 95\% confidence interval did not overlap the baseline of no difference in catch performance, $C C(l, v)=0.5$.

\section{Catch ratio analysis}

Additionally, the ratio between the catch efficiency of the control and test trawl nets for a given length, $l$, was computed with the following expression for the experimental data:

$$
C R_{l}=\frac{\sum_{i=1}^{12} n 2_{l_{i}}}{\sum_{i=1}^{12} n 1_{l_{i}}}
$$

with the following functional form, based on Equations (1) and (4):

$$
C R(l, v)=\frac{C C(l, v)}{1-C C(l, v)}
$$

If the catch efficiency were the same in both trawls, the catch ratio would be equal to 1 . Estimation of mean $C R(l, v)$ and its confidence intervals for each length class was embedded in the double bootstrap analysis explained above.

The catch comparison and catch ratio models were fitted with the help of library lme 4 of the computing package for $\mathrm{R}$ (version 3.3.2), using an ad hoc script. The size frequencies of the standard and the experimental net were compared statistically by means of a Kolmogorov-Smirnov test (command ks.test of $\mathrm{R}$ version 3.3.2).

\section{RESULTS}

The size frequency distributions of the three species under study are reported in Figure 3. The size frequency of hake (Fig. 3, left) was shifted to the right in the experimental trawl, with a modal length of capture around $18 \mathrm{~cm}$ TL, while the mode in the control trawl was $15 \mathrm{~cm}$. In the case of red mullet (Fig. 3, center) the size frequency observed lies in a narrow range of 13 to $22 \mathrm{~cm}$ (10 size classes), with a single peak at 15 $\mathrm{cm}$ for the control trawl and a mode around $16 \mathrm{~cm}$ for the experimental trawl. The striped red mullet (Fig. 3, right) showed a bimodal size frequency for the control trawl, with peaks at 13 and $18 \mathrm{~cm}$, while the experimental trawl produced a larger quantity of individuals in the first mode $(13-14 \mathrm{~cm})$ and a barely noticeable second mode.

A Kolmogorov-Smirnov test of difference between the size frequencies of the standard and the experimental net showed no significant differences (hake, $\mathrm{D}=0.231$, $\mathrm{p}=0.493$; red mullet, $\mathrm{D}=0.203$, $\mathrm{p}=0.995$; striped red mullet, $\mathrm{D}=0.176, \mathrm{p}=0.954)$.

The length-dependent catch comparison analysis for the three species produced the models whose parameters are given in Table 2 and plotted in Figure 4 (left panels). In the case of hake and red mullet, the best models selected included polynomial terms of degrees $0,1,2$, while in the case of the striped red mullet a constant intercept polynomial produced the best results 
Table 2. - Parameter estimates of the selected models (coefficients of the polynomial models in Eq. 2), with 95\% confidence intervals.

\begin{tabular}{|c|c|c|c|c|}
\hline Species & Model & Parameter & Estimate & $95 \% \mathrm{CI}$ \\
\hline Hake (Merluccius merluccius) & Quadratic & $q_{0}$ & $\begin{array}{l}-3.031 \\
0.194\end{array}$ & $\begin{array}{l}-7.125-1.064 \\
-0.203-0.591\end{array}$ \\
\hline & & $\begin{array}{l}q_{1} \\
q_{2}\end{array}$ & -0.0018 & $-0.0114-0.0078$ \\
\hline Red mullet (Mullus barbatus) & Quadratic & $q_{0}$ & -17.672 & $-8.082--27.26$ \\
\hline & & $q_{1}$ & 1.941 & $0.788-3.095$ \\
\hline Striped red mullet (Mullus surmuletus) & Linear & $\begin{array}{l}q_{2} \\
q_{0}\end{array}$ & -0.053 & $-0.086--0.0181$ \\
\hline
\end{tabular}
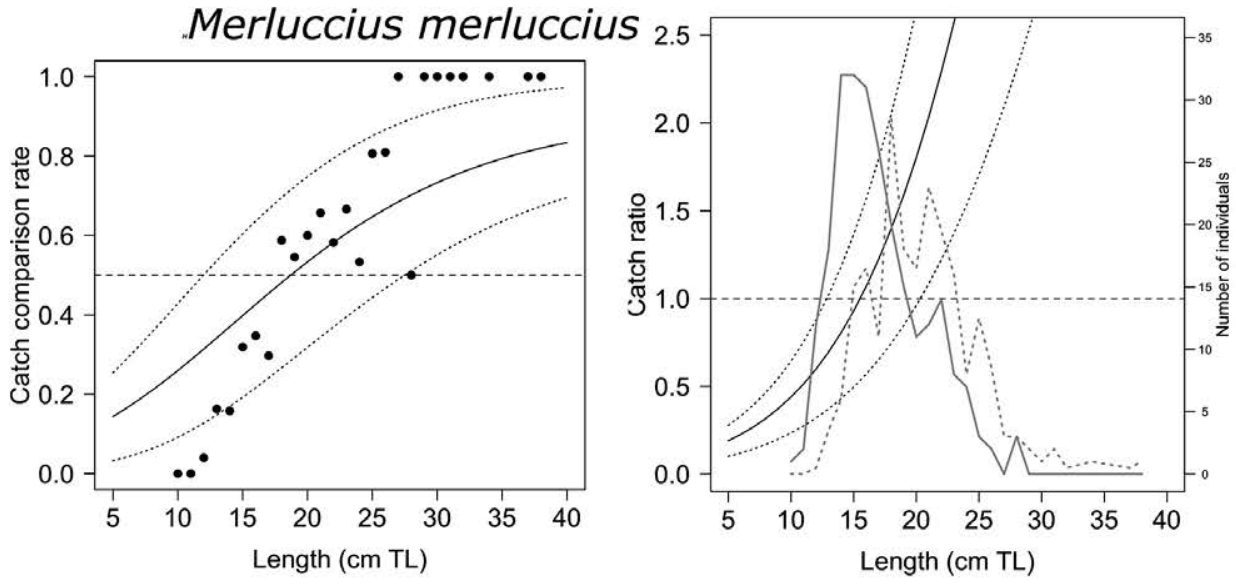

Mullus barbatus
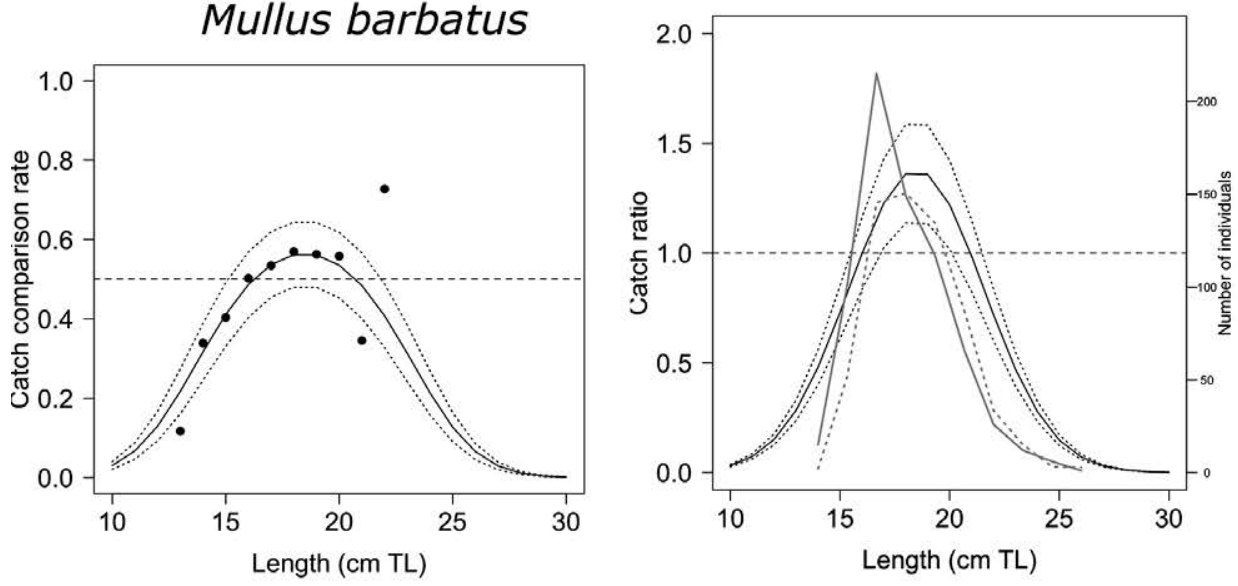

Mullus surmuletus
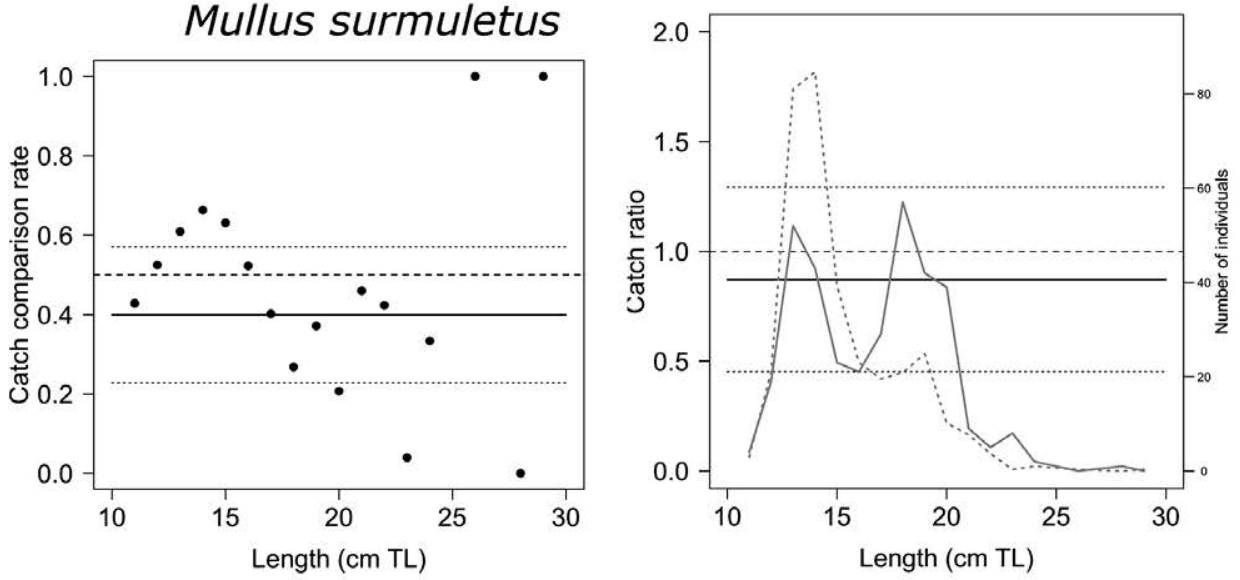

Fig. 4. - (left) Catch comparison curves for the models selected: filled circles are observed proportions, pooling all trawl hauls. Solid lines represent the mean, dotted lines $95 \%$ confidence intervals. The level of no effect $(C C(l, v)=0.5)$ is shown by the horizontal dotted line. (right) Catch ratio curves (solid black lines, mean; dotted black lines, 95\% confidence intervals) and observed catch frequency (grey lines, continuous control trawl; dotted lines, experimental trawl). The level of no effect $(C R(l, v)=1.0)$ is show by the horizontal dotted line. Model parameters are shown in Table 2. 
Table 3. - Fit statistics for the catch comparison curves; df, degrees of freedom; AIC, Akaike information criterion.

\begin{tabular}{lcccc}
\hline Species & AIC & deviance & df & p-value \\
\hline Hake & 286.66 & 278.7 & 130 & 0.98 \\
Red mullet & 341.06 & 333.0 & 93 & 0.99 \\
Striped red mullet & 256.1 & 248.1 & 87 & 0.97 \\
\hline
\end{tabular}

(Table 2). The fit statistics of the models are given in Table 3. The p-values obtained were above 0.05 for all three species, suggesting that the data are well described by the models.

Figure 4 (top, left) shows that the experimental trawl has higher catches of hake larger than $16 \mathrm{~cm}$ (approximately) than the standard trawl, with a strong reduction in catches of individuals in the smaller size classes. In the case of red mullet (Fig. 4, middle, left), a slightly higher, but not statistically significant, rate of catches was detected for individuals in the range $16-20 \mathrm{~cm}$, with significantly reduced catches below $15 \mathrm{~cm}$ in the experimental trawl (confidence intervals below the baseline of 0.5). For striped red mullet (Fig.
4 , bottom, left) the relative catches of 13 to $15 \mathrm{~cm}$ fish were higher in the experimental net, but while the experimental net had lower catch rates for lengths greater than $15 \mathrm{~cm}$, the difference was not statistically significant from the standard trawl (confidence intervals within the baseline of 0.5 ).

The quantitative differences in the catch efficiencies are shown in the catch ratio curves (Fig. 4, right panel). In the case of hake (Fig. 4, top, right) the experimental net caught fewer individuals smaller than $12 \mathrm{~cm}$ and more individuals larger than $20 \mathrm{~cm}$. In the case of red mullet, the catch ratio of the experimental trawl was significantly lower than the standard for sizes below 15 $\mathrm{cm}$ and higher than 23 , with significantly higher catch rates between 17 and $20 \mathrm{~cm}$. The experimental trawl did not produce significant differences in catch efficiency for striped red mullet. Table 4 shows the catch ratios, in percentage, between the two fishing gears (baseline of no effect $=100 \%$ ) for the typical fish sizes collected in the experiments (10 to $25 \mathrm{~cm}$ TL). Although the confidence intervals are wide, the experimental net had

Table. 4. - Estimated catch ratios for different length classes (the majority of individuals of the three species are in the range 10 to $25 \mathrm{~cm}$ ), using the standard trawl as baseline, for the models in Table 2 (see also Fig. 4, right). Values in parentheses are the 95\% CI.

\begin{tabular}{lcc}
\hline Catch ratio $(\%)$ & hake & red mullet \\
\hline CR $(10, v)$ & $43.83(23.35-64.31)$ & $3.15(2.63-3.67)$ \\
CR $(11, v)$ & $51.30(27.33-75.26)$ & $7.29(6.09-8.49)$ \\
CR $(12, v)$ & $59.82(31.88-87.77)$ & $15.18(12.68-17.68)$ \\
CR $(13, v)$ & $69.52(37.04-102.00)$ & $28.45(23.76-33.15)$ \\
CR $(14, v)$ & $80.50(42.89-118.12)$ & $48.01(40.09-55.93)$ \\
CR $(15, v)$ & $92.89(49.50-136.29)$ & $72.94(60.91-84.97)$ \\
CR $(16, v)$ & $106.81(56.91-156.71)$ & $122.82(102.56-143.07)$ \\
CR $(17, v)$ & $122.38(65.21-179.56)$ & $136.14(113.68-158.59)$ \\
CR $(18, v)$ & $139.73(74.45-205.01)$ & $135.85(113.44-158.26)$ \\
CR $(19, v)$ & $158.97(84.70-233.24)$ & $122.05(101.92-142.18)$ \\
CR $(20, v)$ & $180.22(96.02-264.42)$ & $98.71(82.43-114.99)$ \\
CR $(21, v)$ & $203.59(108.48-298.71)$ & $71.87(60.02-83.73)$ \\
CR $(22, v)$ & $229.19(122.11-336.26)$ & $47.12(39.34-54.89)$ \\
CR $(23, v)$ & $257.09(136.98-377.19)$ & $27.80(23.22-32.39)$ \\
CR $(24, v)$ & $287.36(153.11-421.61)$ & $14.77(12.34-17.21)$ \\
CR(25, v) & $320.07(170.54-469.61)$ & $65.74(54.90-76.59)$ \\
CR(average, v) & $150.21(80.03-220.38)$ & $-34.26(-45.10-75.59)$ \\
$\Delta$ CR(average, v) & $50.21(-19.97-219.38)$ &
\end{tabular}

Table 5. - Mean catch composition (weight and value) of 12 hauls with the standard net (DM53) and with the experimental net (T90). Income shown is the ex-vessel value.

\begin{tabular}{|c|c|c|c|c|c|}
\hline & & & & & \\
\hline & & Catch (kg) & Income $(€)$ & Catch (kg) & Income $(€)$ \\
\hline Commercial species & Fishes (total) & 151.8 & 1048.27 & 128.9 & 817.90 \\
\hline & Lophius sp. & 24.9 & 225.10 & 17.9 & 161.82 \\
\hline & M. barbatus & 37.8 & 205.63 & 35.0 & 190.40 \\
\hline & M. surmuletus & 23.9 & 231.35 & 16.2 & 156.82 \\
\hline & Merluccius merluccius & 11.7 & 109.63 & 14.5 & 135.87 \\
\hline & Other taxa & 29.9 & 197.34 & 16.7 & 110.22 \\
\hline & Pagellus erythrinus & 1.9 & 6.27 & 6.5 & 21.45 \\
\hline & Trisopterus minutus & 21.8 & 70.85 & 12.2 & 39.65 \\
\hline & Raja sp. & 1.0 & 2.10 & 0.8 & 1.68 \\
\hline & Cephalopods (total) & 61.9 & 382.67 & 57.8 & 374.60 \\
\hline & Alloteuthis media & 1.7 & 47.11 & 2.0 & 55.42 \\
\hline & Eledone cirrhosa & 16.1 & 79.53 & 15.4 & 76.08 \\
\hline & Illex coindetii & 23.3 & 107.88 & 18.8 & 87.04 \\
\hline & Octopus vulgaris & 4.9 & 20.78 & 6.9 & 29.26 \\
\hline & Sepia officinalis & 2.0 & 28.68 & 3.0 & 43.02 \\
\hline & Sepia orbignyana & 13.9 & 98.69 & 11.8 & 83.78 \\
\hline & Stichopus regalis & 4.8 & 385.92 & 3.6 & 289.44 \\
\hline Total landings & & 219.5 & 1816.86 & 181.1 & 1481.93 \\
\hline Total catches $(\mathrm{kg})$ & & 419.20 & & 354.00 & \\
\hline Discards (kg) & & 199.7 & & 172.9 & \\
\hline Discards ratio (\%) & & 47.6 & & 48.8 & \\
\hline
\end{tabular}


a lower catch efficiency of individuals of $15 \mathrm{~cm}$ TL and below for both hake and red mullet. On the other hand, the average catch efficiency of the experimental net for hake was $150 \%$, i.e. overall it caught $50 \%$ more quantity of hake regardless of size. In the case of red mullet, a loss of $34 \%$ could be expected, and for striped red mullet a loss of $13 \%$ (Table 4 ).

Computing the empirical catch ratio (Eq. 4) for sizes below an MCRS of $20 \mathrm{~cm}$ TL for hake and $11 \mathrm{~cm}$ TL for both red mullets resulted in a value of $52 \%$ for hake, i.e. the experimental trawl caught about half the quantity of undersize hake that the standard trawl caught. In the case of red mullets, no undersize specimens were caught by the standard or the experimental trawl.

In addition to the study target species, the catches of accompanying species of commercial interest was also modified in the experimental trawl, as shown in Table 5. In general, both catches and total discards were lower in the modified net, although the proportion of total discards was similar: $47.6 \%$ and $48.8 \%$ respectively. All fish species except $M$. merluccius and Pagellus erythrinus showed lower catch rates with the modified net. The overall catch of invertebrates (commercial cephalopods and the echinoderm Stichopus regalis) were lower in the modified net, although some species of cephalopods (Alloteuthis media, Octopus vulgaris and Sepia officinalis) showed higher catches. In economic terms, the modified net produced a $17 \%$ decrease in the marketed catch and an $18 \%$ decrease in the commercial value.

\section{DISCUSSION}

Our results show that introducing the T90 mesh in the trawl extension piece reduces the likelihood of capturing small individuals for two important commercial species of Mediterranean fisheries, the European hake (Merluccius merluccius) and the red mullet Mullus barbatus. This result is relevant in terms of fisheries management because these species fall under the Landing Obligation in the transition period 2017-2019. In the case of $M$. merluccius, the adoption of this modification to the trawl extension helps bring L50 well below the MCRS with current trawl regulatory mesh size, more in line with the $20 \mathrm{~cm}$ legal size, while at the same time increasing catch rates. For the two red mullet species Mullus spp., regulatory mesh size already catches individuals larger than the MCRS of 11 and the modification would result in a non-negligible catch reduction.

The introduction of modifications to fishing gear that improve fisheries selectivity will be successful only if these modifications are practical (easy to use and inexpensive), can be acceptable to industry and managers, have low environmental impact and are easily enforceable (Catchpole et al. 2008). Simple modifications to the trawl net such as the one proposed here meet these requirements and are particularly interesting for hake, whose exploitation is excessive and relies to a large extent on undersize individuals. Other authors have shown the selective properties of T90 net- ting either in the codend or the trawl body. T90 netting has interesting properties regarding species and size selection when used in codends. For instance, Deval et al. (2016) tested codends with T90 meshes in four commercial shrimps of eastern Mediterranean trawl fisheries and showed that the percentage of escapes for all four species increases, as well as obtaining an increase in the L50. In Northern European fisheries, T90 codends have been subject to comprehensive studies that show a clear improvement in selectivity (Moderhak et al. 1999) and in the quality of the fish marketed (Hansen 2004). Despite the number of studies carried out with T90 codends, we are not aware of any other studies testing selection at the level of trawl extension.

The proposed modification does, however, significantly reduce the total commercial catch of the vessel, by $17 \%$ in volume and $18 \%$ in value. Most of the species affected by this reduction are bony fishes, in particular small anglerfish (Lophius sp.) and poor cod (Trisopterus minutus). It is expected that the economic loss can be partially offset by decreased sorting time and costs and decreased costs related to compliance with the Landings Obligation, but certainly short-term losses of income are a barrier to the adoption of more selective technologies. Nevertheless, this short-term reduction of commercial catch can be justified by the need to reduce fishing mortality in the Mediterranean demersal fisheries for overexploited target stocks. It should lead to a recovery of stocks and provide higher yields in the medium to long term Merino et al. (2015).

\section{ACKNOWLEDGEMENTS}

This research has received funding from the European Commission's Horizon 2020 Research and Innovation Programme under Grant Agreement No. 634495 for the Science, Technology and Society Initiative to Minimize Unwanted Catches in European Fisheries (MINOUW).

\section{REFERENCES}

Akaike H. 1974. A new look at the statistical model identification. IEEE Trans. Auto. Control 19: 716-722. https://doi.org/10.1109/TAC.1974.1100705

Bahamon N., Sardà F., Suuronen P. 2006. Improvement of trawl selectivity in the NW Mediterranean demersal fishery by using a $40 \mathrm{~mm}$ square mesh codend. Fish. Res.81: 15-25. https://doi.org/10.1016/j. fishres.2006.05.020

Bellido J.M., García-Rodríguez M., García-Jiménez T., et al. 2017. Could the obligation to land undersized individuals increase the black market for juveniles: evidence from the Mediterranean? Fish Fish. 18: 185-194 https://doi.org/10.1111/faf.12166

Catchpole T.L., Revill A. S., Innes J., et al. 2008. Evaluating the efficacy of technical measures: a case study of selection device legislation in the UK Crangon crangon (brown shrimp) fishery. ICES J. Mar. Sci. 65: 267-275. https://doi.org/10.1093/icesjms/fsn016

Deval M.C., Özgen G., Özbilgin H. 2016. Selectivity of 50 mm T0 and T90 codends for commercial shrimp species in the Turkish deepwater trawl fishery, Eastern Mediterranean. J. Appl. Ichthyol. 32: 1041-1057. https://doi.org/10.1111/jai.13128

Efron B. 1982. The jackknife, the bootstrap and other resampling plans. Society for Industrial and Applied Mathematics, CBMSNSF Regional Conference Series in Applied Mathematics Monograph 38, Philadelphia. 85 pp. 
https://doi.org/10.1137/1.9781611970319

European Commission (EC). 2006. European Council Regulation No. 1967/2006 of 21 December 2006, concerning management measures for the sustainable exploitation of fishery resources in the Mediterranean Sea, amending Regulation EEC No 2847/93 and repealing Regulation EC No 1626/94. Official Journal of the European Union, L 409

European Commission (EC). 2012. Proposal for a regulation of the European Parliament and of the Council on the Common Fisheries Policy - general approach. Commission of the European Communities, Brussels 2012 11322/12.

European Commission (EC). 2013. European Council Regulation No 1380/2013 of the European Parliament and of the Council of 11 December 2013 on the Common Fisheries Policy, amending Council Regulations EC No 1954/2003 and EC No 1224/2009 and repealing Council Regulations EC No 2371/2002 and EC No 639/2004 and Council Decision 2004/585/EC. Official Journal of the European Union, L 354.

Guijarro B., Massutí E. 2006. Selectivity of diamond- and squaremesh codends in the deepwater crustacean trawl fishery off the Balearic Islands western Mediterranean. ICES J. Mar. Sci. 63: 52-67. https://doi.org/10.1016/j.icesjms.2005.08.011

Gullestad P., Blom G., Bakke G., et al. 2015. The "Discard Ban Package": Experiences in efforts to improve the exploitation patterns in Norwegian fisheries. Mar. Pol. 54: 1-9. https://doi.org/10.1016/j.marpol.2014.09.025

Hansen U.J. 2004. Performance of a trawl made from $90^{\circ}$ turned netting (T90) compared with that of traditional codends. Gdynia: ICES Fishing Technology and Fish Behaviour Working Group Meeting.

Holst R., Revill A. 2009. A simple statistical method for catch comparison studies. Fish. Res. 95: 254-259. https://doi.org/10.1016/j.fishres.2008.09.027

Krag L.A., Herrmann B., Karlsen J.D. 2014. Inferring fish escape behaviour in trawls based on catch comparison data: model development and evaluation based on data from Skagerrak, Denmark. PLoS ONE 9: e88819. https://doi.org/10.1371/journal.pone.0088819

Madsen N., Herrmann B., Frandsen R.P., et al. 2012. Comparing selectivity of a standard and turned mesh T90 codend during towing and haul-back. Aquat. Living Res., 25: 231-240. https://doi.org/10.1051/alr/2012021

Martinet V., Thébaud O., Doyen L. 2007. Defining viable recovery paths toward sustainable fisheries. Ecol. Econ. 64: 411-422. https://doi.org/10.1016/j.ecolecon.2007.02.036

Merino G., Quetglas A., Maynou F., et al. 2015. Improving the performance of a Mediterranean demersal fishery toward economic objectives beyond MSY. Fish. Res. 161: 131-144. https://doi.org/10.1016/j.fishres.2014.06.010

Moderhak W., Dahm E., Winbeck H., et al. 1999. Determination of selectivity of cod codends made of netting turned through $90^{\circ}$. Bull. Sea Fish. Inst. Gdynia 1140: 3-14.

Sala A., Lucchetti A. 2011. Effect of mesh size and codend circumference on selectivity in the Mediterranean demersal trawl fisheries. Fish. Res. 110: 252-258. https://doi.org/10.1016/j.fishres.2011.04.012

Sartor P., Carbonara P., Luchetti A., et al. 2016. Indagine cognoscitiva sullo scarto della pesca alle specie demersali nei mari italiani. Sintesi del Progetto Coordinato. Project Final Report, Italian Ministry for Agriculture, Food and Forest Policies. Quaderni Nisea n. 1, 40 pp.

Sistiaga M., Herrmann B., Grimaldo E., et al. 2015. Effect of lifting the sweeps on bottom trawling catch efficiency: A study based on the Northeast arctic cod (Gadus morhua) trawl fishery. Fish. Res.167: 164-173. https://doi.org/10.1016/j.fishres.2015.01.015

Tsagarakis K., Palialexis A., Vassilopoulou V. 2014. Mediterranean fishery discards: Review of the existing knowledge. ICES J. Mar. Sci. 71: 1219-1234 https://doi.org/10.1093/icesjms/fst074

Uhlmann S.S., Van Helmond A.T.M., Kemp Stefánsdóttir E., et al. 2014. Discarded fish in European waters: General patterns and contrasts. ICES J. Mar. Sci. 71: 1235-1245. https://doi.org/10.1093/icesjms/fst030

Wienbeck H., Herrmann B., Moderhak W., et al. 2011. Effect of netting direction and number of meshes around on size selection in the codend for Baltic cod Gadus morhua. Fish. Res.109: 80-88.

https://doi.org/10.1016/j.fishres.2011.01.019 